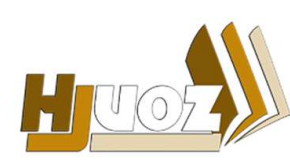

hjuoz.uoz.edu.krd p-ISSN: 2410-7557 e-ISSN: 25185128
كُوّارا زانستيّن مروّفايهتى يا زانكوّيا زاخوّ

مجلة العلوم الانسانية لجامعة زاخو

Humanities Journal of University of Zakho (HJUOZ)

Vol. 6, No. 1, Part 2, pp. 240-255, Mar.-2018
JUOZZ

journals.uoz.edu.krd

\title{
دراسة موقع الضبط لدى طلبة مدارس الإعدادية في مركز قضاء زاخو و علاقته بمتغيرات
}

\section{الاجتماعية و العلمية}

نصرالدين إبراهيم محمد

قسم علم نفس العام، فاكولتي العلوم الانسانية، جامعة زاخو، إقليم كوردستان-العراق (nasraddin.mohammad@uoz.edu.krd). https://doi.org/10.26436/2017.5.3.591 2018/03 2016/01 2016/07 تاريخ الاستلاميخ النشر:

الملخص:

يهدف البحث الحالي الى التعرف على موقع الضبط لدى طلبة مدارس الإعدادية في مركز قضاء زاخو. والتعرف على الفروق تبعاً للمتغيرات

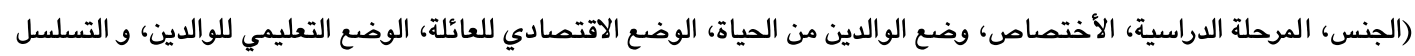

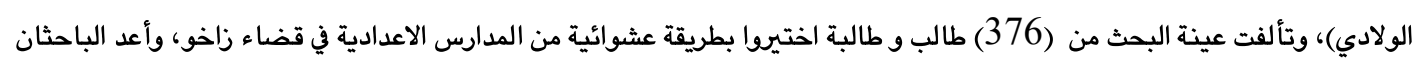

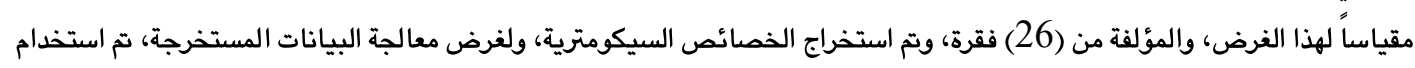

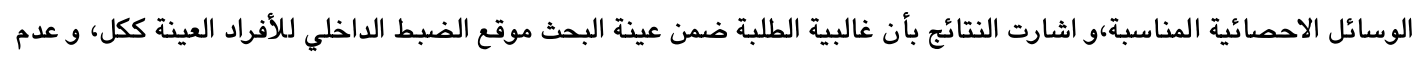

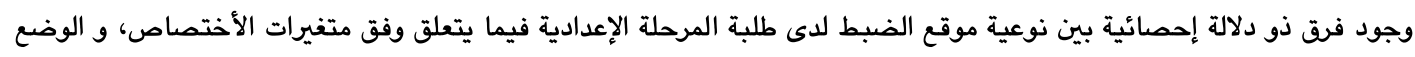

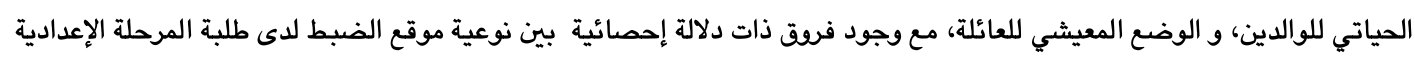

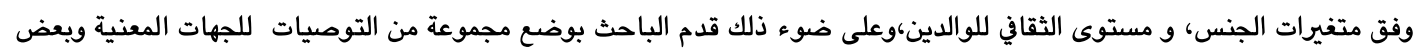
مقترحات للبحوث مستقبلا. الكلمات الدالة: موقع الضبط، طلبة المدارس الإعدادية، قضاء زاخو، متغيرات الاجتماعية و العلمية.

2.

إذا كان التعلم مسئولية الطلبة بالدرجة الاولى، فإن التعليم هو مسئولية جميع أطراف العملية التربوية على جميع مستوياتها، و بذلك لايقتصر

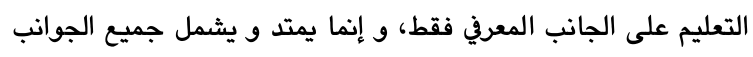
الأخلاقية السلوكية، الترفيهية، النظامية و الإدارية، و الصحية و البيئية، و الإقتصادية و السياسية، ناهيك عن كيفية التعامل مع الآخر مهما كانت حدود الزمان و المكان ( إبراهيم، 2004، 639 )، كما و أن التعليم

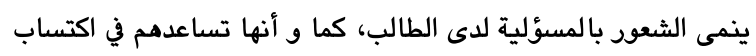

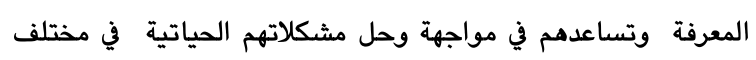

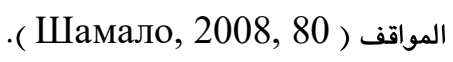
كما و يؤكد بيتر ويلسون ( Peter Wilson ) أن للمدرسة وظائف

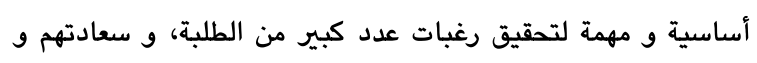

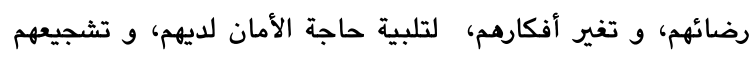

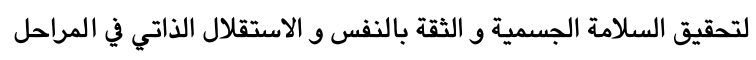
القادمة من حياتهم ، و تنمية الجانب المعرفي و الثقافي و النفسي و و

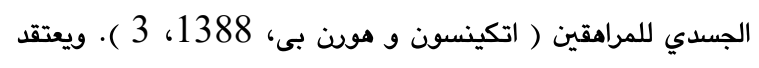
التربويين أن التغيير و التطور الحضاري في ميدان التربية و التعليم في المدراس هو جزء من العملية الواسعة التي تهدف إلى البناء الفكري
1. مشكلة البحث

نظراً للتغيرات الاجتماعية و الاقتصادية و السياسية و التكنولوجية على

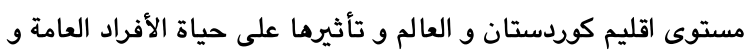
حياة الطلبة التعليمية بصورة خاصة،و تغيير نظرة الطلبة الى أنفسهم و العالم بطريقة خاصة و من جانب آخر من خلال تجربة الباحث ان كثيراً من اباء الطلبة يلقون باللوم لفشل الطلبة و رسويهم في الدراسة على من مانى عاتق المدرسة و المدرسين و الجهات المعنية في وذارة التربية و غيره من الجهات، في حين ان قليل منهم يعتبرن أنفسهم سبباً لذلك. وفي ضوء ماذكر أعلاه يمكن صياغة مشكلة البحث بالتساؤلات الآتية: 1- ما مو موقع الضبط لدى طلبة المدارس الإعدادية في مركز قضاء

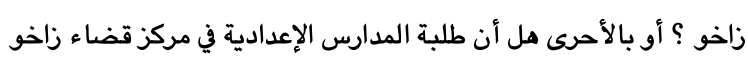
يرجعون سبب فشلهم أو نجاحهم في الحياة العامة و الحياة المدرسية

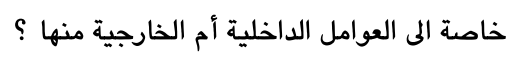

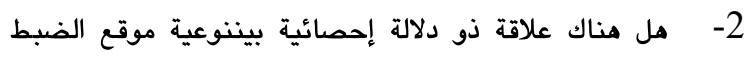

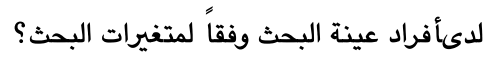




\section{3. اهداف البحث}

$$
\text { يهدف البحث الحالي إلى ما يلي: }
$$

أولاً : التعرف على موقع الضبط لدى طلبة المدارس الإعدادية في مركز

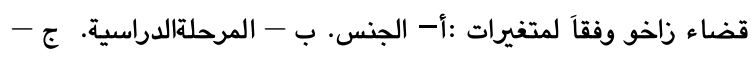
الأختصاص ( العلمي أو أدبي ). د - وضع الوالدين من الصياة:( الأب

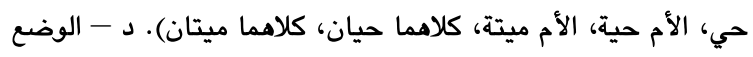

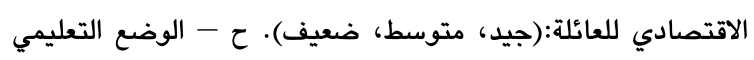
للوالدين: ( الأب متعلم، الأم متعلمة، كلاهما متعلمان، كلاهما غير

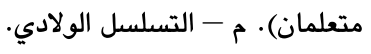

ثانياً : التعرف على الفرق بين موقع الضبط لدى أفراد عينة البحث

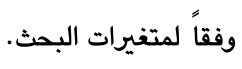

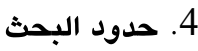

يتحدد البحث الحالي بـطلبة المدارس الإعدادية في مركز قضاء زاخو للعام الدراسي ( 2015- 2016) ومن كلا الجنسين و جميع المراحل.

\section{5. مصطلحات البحث}

تعريف التميمي(1999) لموقع الضبط : مو الكيفية التي يفسر فيها الفرد حوادث النجاح و الفشل في حياته ( الأتروشي، 2013 ، 18 ). تعريف روتر لموقع الضبط الداخلي: درجة نجاح الفرد المتوقعة

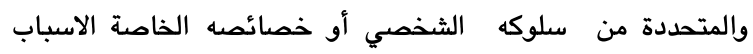

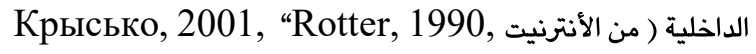

تعريف روتر لموقع الضبط الخارجي: درجة نجاح اوفشل الفرد نتيجة

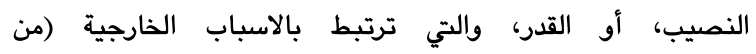

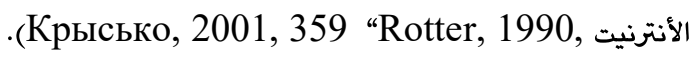
تعريف كولمان لمفهوم موقع الضبط: اسلوب معرفي أو سمة شخصية يوصف على أساس التوفع العام حول العلاقة بين السلوك و التعزيز الواردة بشكل ثواب أو عقاب ( Colman, 2009, 428 ). التعريف النظري لموقع الضبط للباحث: الأسلوب الذي يستخدم الفرد لتفسير الحوادث التي يحدث في حياة الفرد سواءً نجاحه فيها أم فشله في حل الصراعات و مشاكل الحياتية. التعريف الإجرائي: ومما تقدم يعرف الباحث الموقع الضبط اجرائياً بانها: الدرجة الكلية التي سيحصل عليها الطالب / الطالبة على أداة البحث لدى استجابته/ استجابتها على فقراته وتمثل الدرجة نوعية

$$
\text { الموقع الضبط لديه / لديها. }
$$

\section{6. الخلفية النظرية ودراسات سابقة}

Julian ) تعتمد الدراسة الحالية على نظرية جوليان بي. روتر

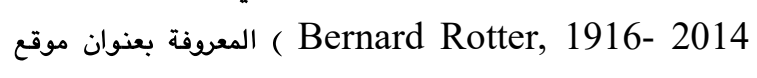

الهادف و اعداد المواطن الصالح و يستدعي ذلك تهذيب المفاهيم و

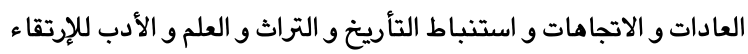

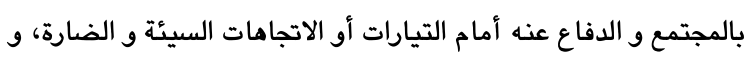

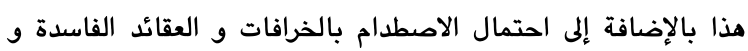
تحويرما ( حسنو دايني، 2006 ، 2135 ). وتعد مرحلة المرامقة من المراحل المهمة و الحساسة في حياة الفرد، و و

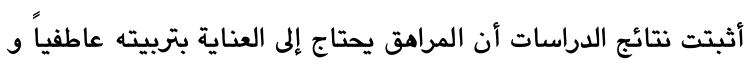

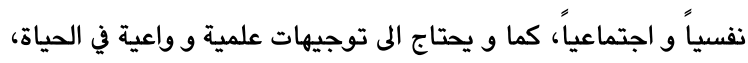

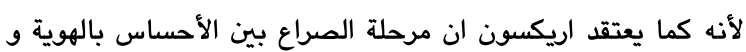
عدم الاحساس بها ( نجاتى، 1389، 9 ، ق قهرهجه تانى، 436، شاملؤ، 2010، 123 )، و من أخطار التفكير الغيبي و إختفاء التفكير العلمي، أن تركن الشخصية الى الكسل و الخمول و عدم السعي

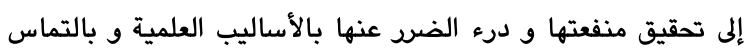
الأساليب الحقيقية و الطبيعية التي تؤدي بها إلى ذلك، و يؤدي بالشخصية إلى الإعتماد على تحقيق أهدافها بوسائل سحرية خرافية، بدلاً من الوسائل الموضوعية. فالعمل الجاد المبني على التخطيط و ربط المقدمات بالنتائج و الأثياء بمسبباتها، هو الذي يوصل الى الهدف، أما الإستكانة على الأفكار الغيبية عن النصيب و القسمة وارضاء إله الحرب أو سخطه، دون السعي و الاجتهاد الجاد لتحقيق الهدف بالوسائل الطبيعية، فهو التخلف بعينه و دمار المجتمع بأكمله

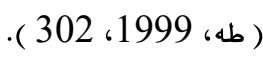
بينت دراسة واينر ( Weiner, 1973 ) ان موقع الضبط الداخلي أعلى لدى الذين يسود لديهم الاعتقاد بأهمية العمل الجاد المستمر بجهد

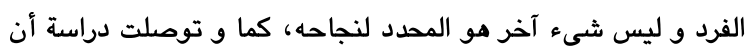
الأشخاص ذوي قيم الإنجاز المرتفعة تكون موقع الضبط لديهم داخلي، كما كانت نسبة غيابهم عن المدرسة أقل من أقرانهم ذوي قيم الإنجاز المنخفضة ( الزيات، 2001، 444 )، كما و وجد المختصيين

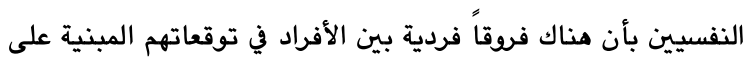
الحظ و تلك المبنية على المهارة مما يؤثر في أدائهم الفردي، مما يرجع إلى اختلاف فهمهم لنتائج عمله و مذا مايعرف بموضوع السيطرة

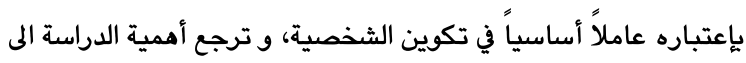
أن موضوع موقع الضبط لدى الفرد يرتبط بالعديد من المتغيرات منها

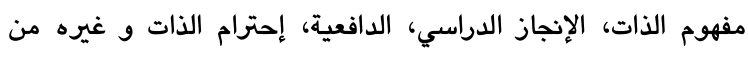

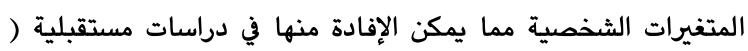
أسمرو، 1989، 339 ) . ومما سبق يمكن القول أن: 1- لموقع الضبط دور في تحديد سلوك و شخصية الفرد الحالية والمستقبلية. 2- - كفاءة الفرد في أي مجال يعتمد على نوعية موقع الضبط لديه.

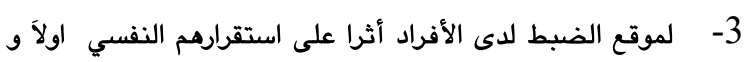
المجتمع وتقدمه ثانيا. 
الآخرين، و يعتبرون أنفسهم ضعفاء و غير قادرين على فعل شىء Jolley “ Ильин, 2000 , 396 “Реан, 1994 , 98) and Mitchell, 1996, 265 (Kreither \& Kinicki, 2004) الداخلي يمشي نحو النتائج، مثل أخذ درجات عالية و جيدة في الامتحانات، و يربط بين حصوله على الدرجات والقليلة و بين عدم التحضير بصورة جيدة. هؤلاء الأفراد يحاولون السيطرة على التشاؤم التماتم لديهم ، و يعتبعن أنفسهم اسياد قدرهم و هم محظوظين، و على العكس هوه يرجعون أصحاب التوجه الخارجي ان الأحداثالسيئة والجيدةالتي تحدث لهم الى الحظ، على سبيل المثال أخذ درجة عالية في الإمتحان في نظرهم قد يرجع الى سهولة الاختبار أو يوم جيد، و عدم تحصيل درجة في الإمتحان برأيهم قد يرجع إلى مشاكلهم العائلية أو سوء الإمتحان

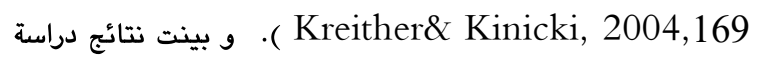
فايندلي و كوبر ( Findley and Cooper, 1983 ) بأن طلبة ذو التوجه الداخلي أكثر نشاطاً و حصيلتهم الدراسية أكثر من الطلبة ذو التوجه الخارجي في الدراسة ( أسدر، 1389 ، 481 ). يرى باندورا بأن الناس قادرون على ملاحضة سلوكهم و ترميزه و تقويمه على أساس ذكريات سلوكهم الماضية اذا لقي تعزيزاً و لم يلقي تعزيزاً و كذلك على أساس عواقب و نتائج مستقبلية متوقعة و بإستخدام المعرفة كنقطة مرجعية ( أحمد، 2003 ، 260 ، 260 ). كما و بينت نتائج دراسة كيبسون و ايفانسفيج و دونلي و كونوباسكى بأن الأفراد ذو إلاتجاه الداخلي أكثر مقاوماً للتغييرات و خاصة تغيير الاتجاهات الشخصية، في حين ان الأفراد ذوىالتوجه الخارجي أكثر سibson, ) سهولة في قبول اتخاذ القرارات المتعلقة بعملهم الانهي Ivancevich, Donnely and Konopaske,2006, 117 )، و في كلا النوعين من الضبط يلعب التعزيز دوراً مهماً في زيادة القدرة في مركز السيطرة أو على التحكم بالأحداث، إذ يعتمد أصحاب النظرية أن تصرفات الأفراد في المواقف المختلفة أو بناء شخصيتهم تتأثر بكيفية إدراكهم لتلك المواقف أو يعتمد على سلوكهم الشخصي و الداخلي(العبيدي و ولي، 2009، 337 ، أسمرو، 1989، 336 . Kellogg and Pisacreta, 2003, 537 ، و أشارت نتائج الدراسات إلى أن تعليل الأفراد لفشلهم يحدد إستجاباتهم اللاحقة له، حيث إن التدهور في الأداء و إنخفاض الدافعية و سيطرة الإنفعال السلبي يوافق الحالات ألتي يعزف الأفراد فشلهم فيها إلى قلة الكفاءة أو نقص القدرة، في حين ان الحالات ألتي يعزف فيعا الأفراد فشلهم إلى عوامل خاضعة لتحكمه فإنه لايرافقها مثل مذه الإستجابات

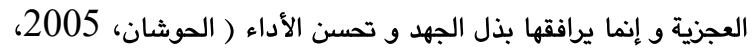

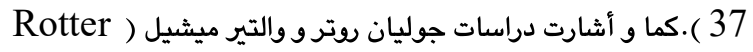
( أن مناك علاقة وطيدة بين الصحة النفسية و بين (and Mischel نوعية التوقع الأحداث لدى الفرد، حيث ان الأفراد ذوى التوجه الداخلي
الضبط ( locus of control ) التي تعد من النظريات الصغرى و المعاصرة بخصوص دراسة و قياس الشخصية ، المصطلح التي

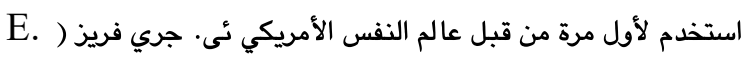

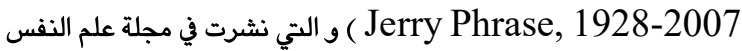
الإجتماعي و غير العاديين في سنة ( 1957 )، كما سميت النظرية ضمن نظريات التعلم الاجتماعي، التي نشرت في مجلة (psychological monographs 1966 ) تحت عنوان " تعميم التوقعات نحو الضبط الداخلي في مقابل

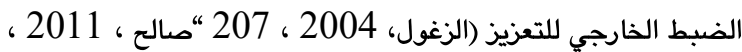
Хок, 2008, “ Jones and George, 2006, 733“ 229 315، Coon, 1997, 495 )، حيث أصبحت أساسا للكثير من الدراسات في نظريات التعلم المعرفي و فيما بعد أصبحت مقياس لقياس موقع الضبط لدى الأفراد و المتكون من ( 29 ) فقرة مزدوجة Myers, 2005, 58 "Passer and Smith, 2008 , 479) “ من الأنترنيت، ب. ت. , Rotter, ). تعد نظرية روتر امتداداً للتعامل بالنمذجة و التقليد، إذ تشترك مذه النظريات في التركيز على أهمية التفاعل الإجتماعي بين الفرد و مجتمعه، حيث أن المجتمع يعمل على تعزيز أو عقاب السلوكات الصادرة عن الفرد و يقرر عليه على أساس بـ نتائجه ( البكري و عجور، 2008، 64 ) ).بالرغم من أنالعالم الاجتماعي تالكوت بارسونز ( T. Parsons ) و بيتر برجر ( P. Berger ) استخدموا مفهوم الضبط في نظرياتهم الاجتماعية ( الترتوري و القضاة، 2006، 184 )، الآ ان فضل استخدامه يرجع إلى روتر. تستخدم النظرية بعض المفاهيم و منها التوقع، و القيم التعزيزية، و مفهوم رئيسي اخر و هو القدرة على التحكم بالأحداث سواء أكان هذا

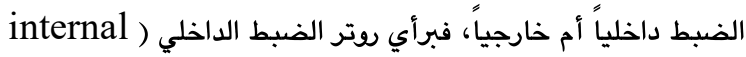
locus تصرفات الفرد أو بناءً على إمتلاكه خصائص دائمية نسبياً كالقابلية و المهارات و الكفايات و القدرات العقلية ألتي تشعره بأنه قادر على إنى التحكم بالنتائج المستقبلية. أما الضبط الخارجي ( external locus

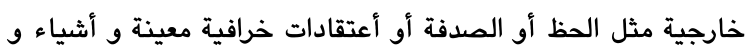
أشخاص أخرين

Резник и Смирнов, “ Медведев, 2003, 202 ) Дружинин, 2000 “Хок, 2008, 316 “ 2002, 18 Харм3, 2002, "Meyers, 2004, 605 “ , 65 210" Burger, 1997, 404 " فبرأي النظرية الأفراد ذو التوجه الداخلي في الضبط يعتقدون بأنهم قادرين على الإبداع و التغيير أو أو الترائ التخلي عن المواقف، و هو سيد الموقف و المسقبل، و أنهم قادرين

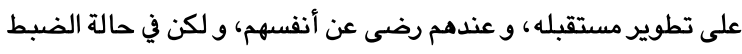
الخارجي يعتقد الأفراد بأنهم تحت رحمة الأحداث الخارجية و الناس 
الظروف و إنما من تفسير الإنسان و تقيمه لتلك الظروف و الأحداث

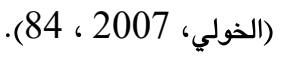

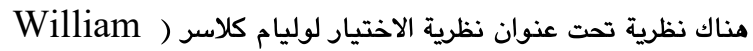

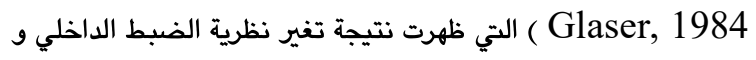
الخارجي، و تتجلي أهمية النظرية في أنها لاتقتصر على مجال العلاج و

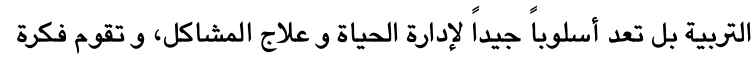
النظرية اساساً على تجنب الفكرة الشائعة التي تدعوا إلى التحكم الخارجي في سلوك و حياة الآخرين، و ذلك لإعتقادهم إن كل ما يختارونه للفرد هو الصواب و مايفعله الآخر هو الخطأ و هو اتجاه يعتمد على الإدراك و يربط بينه و بين السلوك غير المسؤول، السلوك التي يستدعي هو هون هون إيذاء الآخرين و يركز على أن الفرد هو كائن عقلاني و مسؤول عن

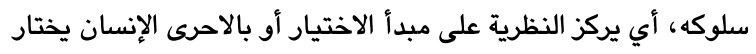
سلوكه سواء أكان إيجابياً و بناءً أم سلبياً و مدمراً ( بكر، 2013 ، 60). الدراسات السابقة:بعد إطلاع الباحثين الواسع على الدراسات السابقة قام بعرض عدد منها و كما يأتي: 1. دراسة أسمرو ( 1989 ) الموسوم بتقنين مقياس القدرة على وكلى التحكم بالأحداث، طبقت على عينة من تلاميذ المرحلة المتوسطة في

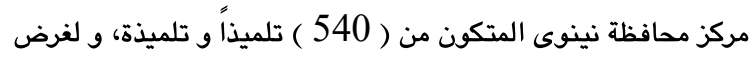
ذلك استخدم مقياس متكون من ( 35 ) عبارة و بعد القيامبالاجراءات المتعلقة بالمعالجات الإحصائية بينت نتائج الدراسة بأن القيمة المحسوية ذات دلالة أحصائية. استخدمتطريقة التجزئة النصفية و إعادة الإختبار لقياس ثبات المقياس ( أسمرو، 1989 ، 335-356 ). 2. دراسة علي( 1990 ) الموسوم بالموقع الضبط لدى أبناء الشهداء و أقرانهم الذين يعيشون مع آبائهم في المرحلة المتوسطة، و تم بمات تطبيق مقياس ناويكي ستريكلاند للأطفال على ( 449 ) طالب و طالبة أرانه و بينت النتائج أن ليس هناك فرق ذات دلالة احصائية بين مجموعة أبناء الشهداء و مجموعة التكافؤ، كما أن بنات الشهداء كن أكثر توجهاً نحو الضبط الخارجي من الذكور و الاناث من غير بنات الشهداء (الموسوي، عبدالرذاق و العجيلي، 2002، من الدور و 19 ). 3. دراسة جاي (1995) الموسوم بموقع الضبط و علاقته بالتوافق النفسي و الاجتماعي لطلبة جامعة بغداد، حيث استخدمت فيها مقاييس موقع الضبط و التوافق النفسي و الاجتماعي، و الوسائل الإحصائية: تحليل التباين الثلاثي و طريقة شيفية و معامل بيرسون و معادلة آلفا و

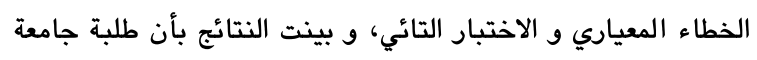
بغدا ذوق موقع ضبط خارجي، و أن ذوي ضبط الداخلي أقدر على ولى بلى التوافق النفسي و الاجتماعي (الموسوي، عبدالرزاق و العجيلي، 2002، 241 ) 2002

4. دراسة الرايات ( 1997 ) الموسوم بأساليب التنشئة الاسرية و علاقتها بمركز الضبط و التحصيل الدراسي لدى طلبة المراجعين لمركز

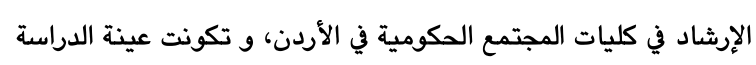

أكثر قادرين على القيام بالسلوكيات الصحيحة نحو انحرافاتهم السلوكية و بالتالي نحو العلاج و السيطرة على الاضطرابات الداخلية المتعقة بالعمل) Sarafino, 2006, 165 Rotter and Mischel, 2015 ). كما و قام والتير ميشيل من الترنيت بدراسة علمية مبنية على أعمال روتر و باندورا و حدد محددات سلوك

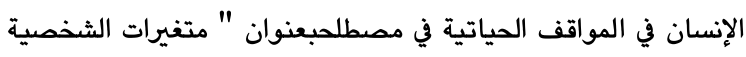
"، المتكونة من قدرات الفرد التي يستطيع بها مواجهة التحديات والمشكلات ،المحسوسة، التي يحس بها الفرد من المحيط، و التوقعات، التي يتوقع الفرد أن تكون نتيجة سلوكه، و قيمة الموضوع، أو أهداف الفرد و اعتقاداته، و تنظيم الذات و خطط الفرد المستقبلية، أو معاييره

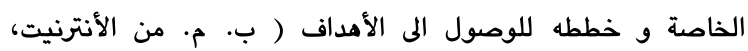
http://psychology.jrank.org/pages/593/Social. Learning-Theory.html اقترح جوليان روتر، في كتابه التعلم الاجتماعي وعلم النفس السريري (1954) أن تأثير السلوك يلعب دورا في دفع المرء إلى اتخاذ إجراء تجاه هذا السلوك، فالناس تنفر من النتائج السلبية، بينما ترغب الإيجابية. فإن توقع المرء أن يعود سلوك معين بنتائج إيجابية، أو رأى احتمالية كبيرة في ذلك، تزداد قابلية مشاركتهم الآخرين في هذا السلوك. إن تعزيز السلوك بالنتائج الإيجابية يقود المرء إلى تكرار انتهاجه. ولذلك ترى نظرية التعلم الاجتماعي أن التأثير على السلوك لا ينحصر فقط بالعوامل النفسية، وإنما تلعب القيم و التوقعات و المحفزات والعوامل

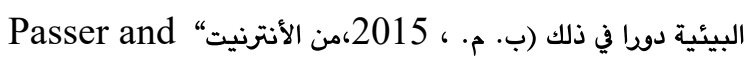
.(Smith, 2007, 566

و في نظريته الموسومة بنظرية الإسقاط ( attribution theory ) و المستندة على ألاسس المعرفية يؤكد واينر ( Winer, 1979 ) أن التحليل و التفسير السببي للنجاح و الفشل لدى الفرد أكثر فائدة من التركيز على الحاجات و الدوافع و الخصائص و السمات الإنفعالية لديهم

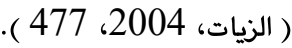
يرى روتر أن سلوك الأفراد لايكون محكوماً بدوافعهم الأولىة للحصول على السروأو تخفىض الحافز كما يرى مل و دولارد و مىلرو لكنه يكون محكوماً بتوقعاتهم التي تحدد مدى تقدمهم نحوأهدافهم الموجهة بدوافعهم، و أن التعزيزات التي يتلقاها الأفراد تدعم تقدمهم نحو لامد الأهداف المشبعة لدوافعهم، ويتفق روترفي مذا مع قانونا لأثرلثورنديك محدداً مفهوم التعزيزبأنه أي فعلأ وحدثأ وشرط فيؤثرعلى حركة الفرد تجاه الهدف ( بركات، 2015، الأنترنيت).

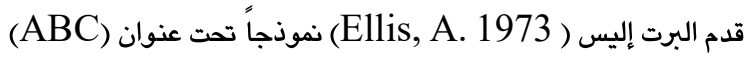
ليوضح تطور الاضطرابات الإنفعالي على أساس إفتراض ان ان الاضطرابات تنتج نتيجة التفكير غير العقلاني الذي تبناه الفرد و لذلك يعتقد أن السبيل الوحيد للتخلص منها هو التخلص من أنماط التفكير الخاطئة و غيرالعقلانية، لأن المشكلات النفسية لاتنجم من الأحداث و 


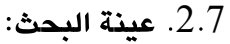

تم اختيار (376) طالباً وطالبة من طلبة جميع المراحل الاعدادية بواقع (172) طالب و (204) طالبة، و يشير مصادر أحصائية أن هذة

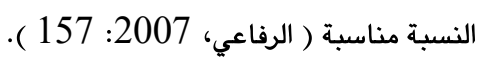

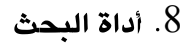

لتحقيق أهداف البحث و اعتماداً على دراسات سابقة و خاصة دراسة

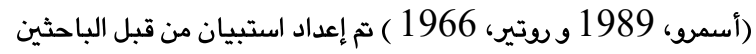

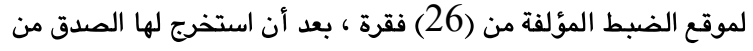

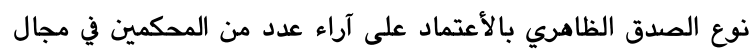

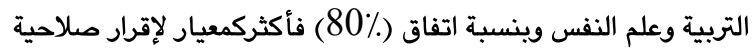
كل فقرة وظهر بان جميع الفقرات قد حصلت على نسبة اتفاق (80) مع إجراء تعديلات طفيفة على بعض تلك الفقرات ويذلك اصبحت جميعها صالحة. فضلاً عن استخراج معامل الثبات لمقياس بطريقة الإعادة و

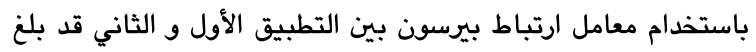

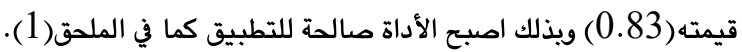

1.8. تطبيق الأداة وتصديحهما: تم تطبيق الاداة بصيغتها النهائية على (376) طالب و طالبة من طلبة الادية

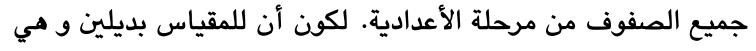

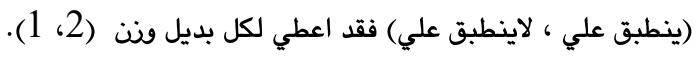

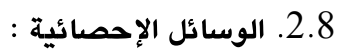

لغرض معالجة البيانات الواردة في البحث ثم الأستعانة بالحقيبة

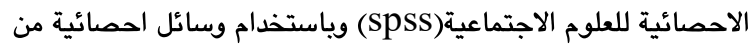
معامل ارتباط بيرسون والاختبار التائي (t.test) لعينة واحدة ولائية والاختبار التائي (t.test) لعينتين مستقلتين وتحليل التباين الثنائي.

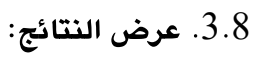

سيتم عرض النتائج وفقا لأهداف البحث وكما يأتي :

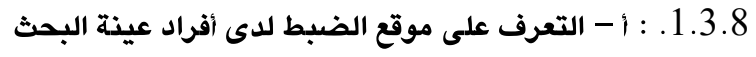

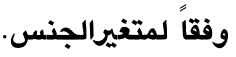

من 120 طالب و طالبة، و طبقت عليهم مقياس مركز الضبط الداخلي و الخارجي المعد من قبل الباحث، و أظهرت النتائج أن هناك علاقة بين

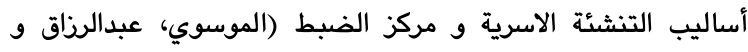
العجيلي، 2002، 405 ).

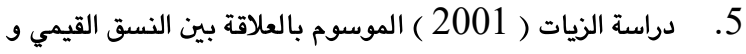

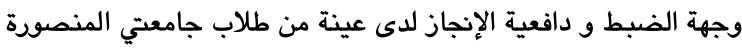

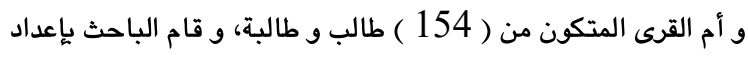
اختبار وجهة الضبط بنفسه و بينت النتائج بعدم اختلاف موقع الضبط بإختلاف النسق القيمي لدى أفراد العينة، كما و بينت أن أفراد العينة

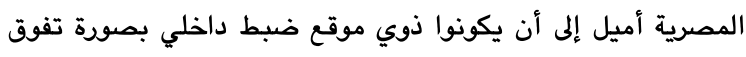
أفراد العينة السعودية، و أن الذكور ذوي موقع داخلية بصورة تفوق الفرق

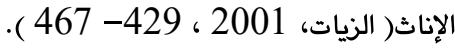
6. دراسة علي ( 2002 ) لغرض الكشف عن العلاقة بين الصحة

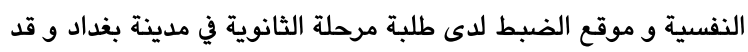
تألفت عينة الدراسة من ( 800 ) طالب و طالبة وقد استخدمت الباحثة النة

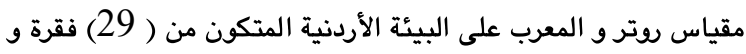

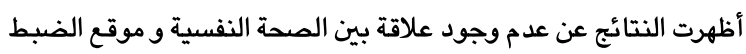

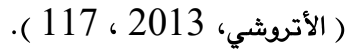

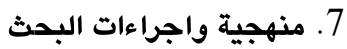

تم اعتماد المنهج الوصفي من نوع المقارنة لتحقيق امداف البحث الحالي مع الاعتماد على عدة اجراءات خاصة بتحديد المجتمع واستخدام الادوات اللازمة لتحقيق اهداف البحث واختيار الوسائل الاحصائية المناسبة التي يمكن توضيحها كما يأتي:

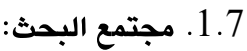
شمل مجتمع البحث طلبة المرحلة الاعدادية في قضاء زاخو والبالغ

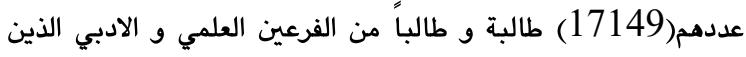
شملتهم الدراسة كما موضح في الجدول (1).

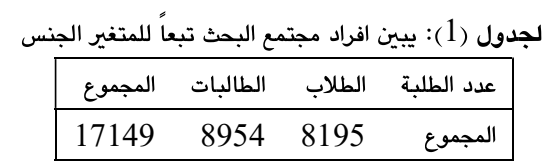
الجدول (2): يبين المجموع و المتوسط النظري لأفراد العينة و نوعية الضبط لكل فئة

\begin{tabular}{|c|c|c|c|c|c|c|}
\hline \multirow[t]{2}{*}{ نوع الضبط لدى الفئة } & \multicolumn{2}{|c|}{ الضبط الخارجي } & \multicolumn{2}{|c|}{ الضبط الداخلي } & \multirow[t]{2}{*}{ 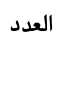 } & \multirow[t]{2}{*}{ الجنس } \\
\hline & المتوسط & المجموع & المتوسط & المجموع & & \\
\hline الداخلي & 15.98 & 2749 & 18.67 & 3212 & 172 & ذكور \\
\hline الداخلي & 16.91 & 3450 & 18.50 & 3775 & 204 & أناث \\
\hline & & & & & 376 & المجموع \\
\hline
\end{tabular}

كما هو موضح من الجدول جميع الطلبة بالرغم من الاختلاف في الجنس )، كما و لدى الطالبات في حالة ( الضبط الداخلي = 18.50 ) مأكبر من المتوسط الحسابي لنفس الفئة في حالة ( الضبط الفيط الخارجي

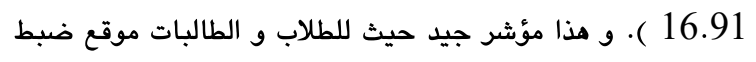
داخلي مما يشير إلى ثقتهم بأنفسهم و قدراتهم و استعداداتهم في الحياة

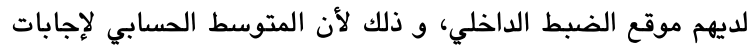

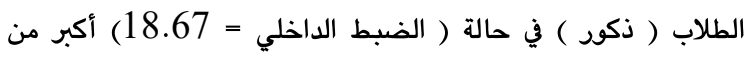

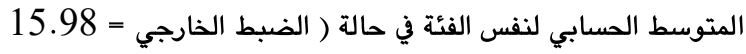


ب - التعرف على موقع الضبط للى أفراد عينة البحث وفقا

لمتغير المرحلةالدراسية.
بصورة عامة و حياة مدرسية بصورة خاصة،و تتفق مذه النتيجة مع

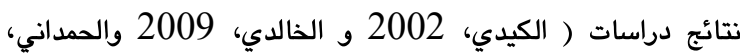

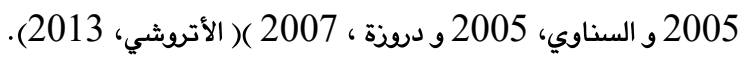

الجدول (3): يبين المجموع و المتوسط النظري لأفراد العينة و نوعية موقع الضبط لدى أفراد عينة البحث وفقاً لمتغير المرحلةالدراسية.

\begin{tabular}{|c|c|c|c|c|c|c|}
\hline \multirow{2}{*}{ نوع الضبط لدى الفئة } & \multicolumn{2}{|c|}{ الضبط الخارجي } & \multicolumn{2}{|c|}{ الضبط الداخلي } & \multirow[t]{2}{*}{ العدد } & \multirow[t]{2}{*}{ لمرحلة الدراسية } \\
\hline & المتوسط & المجموع & المتوسط & المجموع & & \\
\hline الداخلي & 16.73 & 2543 & 18.7 & 2842 & 152 & مرحلة 10 \\
\hline الداخلي & 16.56 & 1788 & 18.69 & 2108 & 108 & مرحلة 11 \\
\hline الداخلي & 16.10 & 1868 & 18.34 & 2127 & 116 & مرحلة 12 \\
\hline & & & & & 376 & المجموع \\
\hline
\end{tabular}

لقد بينت النتائج في الجدول (3) أن جميع الطلبة في جميع المراحل ذو المتوسطات النظري للضبط الخارجي لنفس المراحل الثلاثة ( 16.73

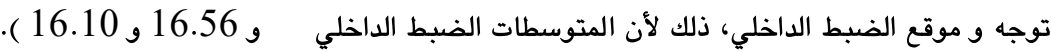
للمراحل الثلاثة المتوالية ( 18.7 و 18.69 و 18.34 ) أكبر من ج ع - التعرف على موقع الضبط لدى الفيط أفراد عينة البحث وفقاً لمتغير الأختصاص ( العلمي أو أدبي ).

الجدول (4): يبين المجموع و المتوسط النظري لأفراد العينة و نوعية الضبط لكل اختصاص

\begin{tabular}{|c|c|c|c|c|c|c|}
\hline \multirow[t]{2}{*}{ نوع الضبط لدى الفئة } & \multicolumn{3}{|c|}{ الضبط الخارجي } & \multirow{2}{*}{ الضجبط الداخلي } & \multirow[t]{2}{*}{ العدد } & \multirow[t]{2}{*}{ الأختصاص } \\
\hline & المتوسط & المجموع & المتوسط & & & \\
\hline الداخلي & 16.61 & 3371 & 18.54 & 3763 & 203 & علمي \\
\hline \multirow[t]{2}{*}{ الداخلي } & 16.35 & 2828 & 18.64 & 3224 & 173 & أدبي \\
\hline & & & & & 376 & المجموع \\
\hline
\end{tabular}

لقد بينت النتائج في الجدول (4) أن جميع الطلبة في اختصاصات العلمية د - التعرف على موقع الضبط لدى أفراد عينة البحث وفقاً

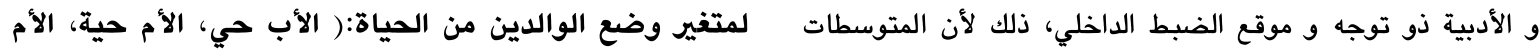

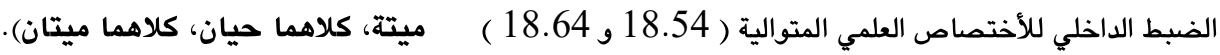
أكبر من المتوسطات النظري للضبط الخارجي لنفس الأختصاصات بصورة متوالية ( 16.61 و 16.35 ).

الجدول (5): يبين المجموع و المتوسط النظري لحالة أفراد العينة و نوعية الضبط لكل فئة

\begin{tabular}{|c|c|c|c|c|c|c|}
\hline \multirow[t]{2}{*}{ نوع الضبط لدى الفئة } & \multicolumn{2}{|c|}{ الضبط الخارجي } & \multicolumn{2}{|c|}{ الضبط الداخلي } & \multirow[t]{2}{*}{ 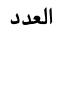 } & \multirow{2}{*}{ قيد الحياة } \\
\hline & المتوسط & المجموع & المتوسط & المجموع & & \\
\hline الداخلي & 16.48 & 5932 & 18.63 & 6705 & 360 & الأب حي \\
\hline الداخلي & 16.69 & 267 & 17.63 & 282 & 16 & الأب ميت \\
\hline الداخلي & 16.53 & 6032 & 18.58 & 6782 & 365 & الأم حية \\
\hline الداخلي & 15.18 & 167 & 18.64 & 205 & 11 & الأم ميتة \\
\hline & & & & & 376 & المجموع \\
\hline
\end{tabular}

لقد بينت النتائج في الجدول (5) أن جميع الطلبة برغم من اختلافهم في ع - التعرف على موقع الضبط لدى أفراد عينة البحث وفقا أن يعيش والديهم أو ميتين لديهم توجه و موقع الضبط داخلي. لمتغير الوضع الاقتصادي للعائلة:(جيد،متوسط، ضعيف) الجدول (6): يبين المجموع و المتوسط النظري لأفراد العينة و نوعية الضبط وفق مستوى المعيشي للعائلة

\begin{tabular}{|c|c|c|c|c|c|c|}
\hline \multirow{2}{*}{ نوع الضبط لدى الفئة } & \multicolumn{2}{|c|}{ الضبط الخارجي } & \multicolumn{2}{|c|}{ الضبط الداخلي } & \multirow{2}{*}{ 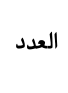 } & \multirow{2}{*}{ مستوى المعيشي للعائلة } \\
\hline & المتوسط & المجموع & المتوسط & المجموع & & \\
\hline الداخلي & 16.99 & 2684 & 18.41 & 2909 & 158 & جيد \\
\hline الداخلي & 16.16 & 3378 & 18.67 & 3901 & 209 & متوسط \\
\hline الداخلي & 15.22 & 137 & 19.67 & 177 & 9 & ضعيف \\
\hline & & & & & 376 & المجموع \\
\hline
\end{tabular}


لقد بينت النتائج في الجدول (6) أن جميع الطلبة برغم من اختلاف م-التعرف على موقع الضبط لدى أفراد عينة البحث وفقاً مستوى المعيشي لعائلاتهم ذو موقع الضبط الداخلي، و هذا يشير الى لمتغير الوضع التعليمي للوالدين:( الأب متعلم، الأم متعلمة،

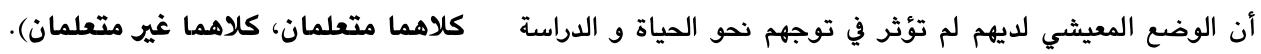
بصورة عامة.

\begin{tabular}{|c|c|c|c|c|c|c|}
\hline \multirow[t]{2}{*}{ نوع الضبط لدى الفئة } & \multicolumn{3}{|c|}{ الضبط الخارجي } & \multirow{2}{*}{ المجموع الضبط الداخلي } & \multirow[t]{2}{*}{ 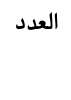 } & \multirow[t]{2}{*}{ مستوى الثقافي للوالدين } \\
\hline & المتوسط & المجموع & المتوسط & & & \\
\hline الداخلي & 16.74 & 1205 & 18.21 & 1311 & 72 & كلتامما يقرءان \\
\hline الداخلي & 16.31 & 2791 & 18.58 & 3215 & 173 & كلتاهما لايقرءان \\
\hline الداخلي & 16.79 & 1914 & 18.86 & 2150 & 114 & فقط الأب يقراء \\
\hline \multirow[t]{2}{*}{ الداخلي } & 17.00 & 289 & 18.29 & 311 & 17 & فقط الأم تقراء \\
\hline & & & & & 376 & المجموع \\
\hline
\end{tabular}

لقد بينت النتائج في الجدول (7) أن جميع الطلبة بالرغم من الاختلاف بينت نتائج على وجود ( 14 ) نوع من البن تسلسل الولادي لدى عينة

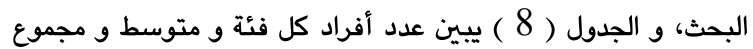

المستوى الثقافي للوالدين ذو توجه موقع الضبط الداخلي. ي - التعرف على موقع الضبط لدى أفراد عينة البحث وفقاً كلتا موقع الضبط الداخلي و الخارجي لأفراد العينة: لمتغيرالتسلسل الولادي. الجدول (8): يبين المجموع و المتوسط النظري لتسلسل الولادي لأفراد العينة و نوعية الضبط لكل تسلسل

\begin{tabular}{|c|c|c|c|c|c|c|}
\hline \multirow[t]{2}{*}{ نوع الضبط لدى الفئة } & \multicolumn{2}{|c|}{ الضبط الخارجي } & \multicolumn{2}{|c|}{ الضبط الداخلي } & \multirow[t]{2}{*}{ العدد الع } & \multirow{2}{*}{ الولادي } \\
\hline & المتوسط & المجموع & المتوسط & المجموع & & \\
\hline الداخلي & 16.33 & 1176 & 18.71 & 1347 & 72 & 1 \\
\hline الداخلي & 17.00 & 635 & 18.44 & 1014 & 55 & 2 \\
\hline الداخلي & 16.65 & 866 & 19.17 & 997 & 52 & 3 \\
\hline الداخلي & 16.49 & 841 & 18.59 & 948 & 51 & 4 \\
\hline الداخلي & 16.48 & 758 & 18.33 & 843 & 46 & 5 \\
\hline الداخلي & 16.70 & 451 & 18.37 & 496 & 27 & 6 \\
\hline الداخلي & 16.10 & 467 & 18.34 & 532 & 29 & 7 \\
\hline الداخلي & 16.44 & 296 & 18.72 & 337 & 18 & 8 \\
\hline الداخلي & 16.14 & 226 & 17.64 & 247 & 14 & 9 \\
\hline الداخلي & 14.20 & 71 & 18.80 & 94 & 5 & 10 \\
\hline الداخلي & 14.00 & 28 & 21.50 & 43 & 2 & 11 \\
\hline الداخلي & 17.00 & 34 & 18.50 & 37 & 2 & 12 \\
\hline الداخلي & 16.00 & 32 & 18.00 & 36 & 2 & 13 \\
\hline الخارجي & 18.00 & 18 & 16.00 & 16 & 1 & 17 \\
\hline & & & & & 376 & المجموع \\
\hline
\end{tabular}

نظرة هذا الطالب الى الصياة متشائمة و ذو موقع الضبط الخارجي بسبب كثرة أفراد العائلة مما تؤثر سلباً على توجهة نحو الحياة بصورة عامة و نحو نفسه بصورة خاصة. 2.3.8. بالنسبة للهدف الثاني حول وجود فروق ذات دلالة إحصائية وفق متغيرات البحث: أ-هناك فروق ذات دلالة احصائية بين موقع الضبط لدى أفراد عينة البحث وفقاً لمتغيرالجنس.
كما مو موضح في الجدول (8) طلبة جميع الفئات لديهم نمط الضبط الداخلي، و هذا المستوى المقبول من الاتجاه الإيجابي من شأنه يجعلهم يعتقدون بأنهم مسؤولون عن نجاحهم و إخفاقاتهم في الحياة من خلال كل ما يقومون به من السلوكيات و أفعال ناجحة أو الفاشلة منهم. التسلسل الولادي ( 17 ) هو الشخص الذي بين ان عنده التوجه الخارجي و برغم من انه وحيد في فئة التسلسل الولادي (17)، و من الصعب تعميم نظرته على الأخرين و حالات متشابهة، و يعزى الباحث 
الجدول (9): دلالة الفرق بين المتوسط الحسابي و النظري والقيم التائية المحسوية و الجدولية لدرجات الطلبة حسب الجنس

\begin{tabular}{|c|c|c|c|c|c|c|c|}
\hline \multirow{2}{*}{ 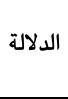 } & \multirow{2}{*}{ مستوى الدلالة و درجة } & \multicolumn{2}{|c|}{ القيمة التائية } & \multirow{2}{*}{ الانحراف } & \multirow{2}{*}{ المتوسط الحسابي } & \multirow{2}{*}{ 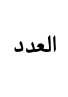 } & \multirow{2}{*}{ المجموعة } \\
\hline & & الجدولية & المحسوية & & & & \\
\hline \multirow{2}{*}{ دالة } & 0.05 & \multirow{2}{*}{2.326} & \multirow{2}{*}{2.626} & 3.056 & 34.66 & 172 & الذكور \\
\hline & (374) & & & 2.449 & 35.42 & 204 & الأناث \\
\hline
\end{tabular}

تم معالجة البيانات إحصائياً باستخدام نظام ال ( SPSS ) و الإختبار أكثر للمغامرة و التفكير في مشاكل الحياة حيث يقع على عاتقهم مسؤلية التائئي لعينيتين مستقلتين، فأظهرت النتائج بوجود فرق ذات دلالة أكثر من البنات مما يؤثر على نظرتها إلى الحياة بصورة متشائمة أكثر

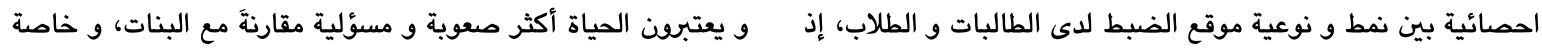

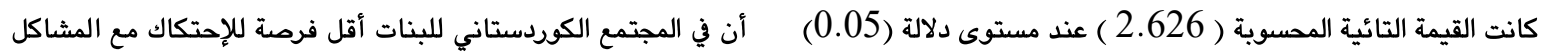

و درجة الحرية ( 374 ) أكبر من القيمة التائية الجدولية ( 2.326 )، المعيشية و التي قليلا ما تتدخل في الشؤون الحياتية و المعيشية.

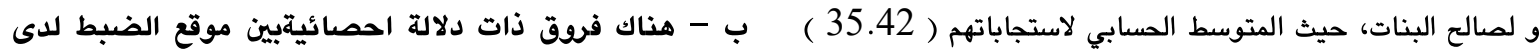
أكبر من التوسط الحسابي لاستجابات البنين ( 34.66 )، و الجدول أفراد عينة البحث وفقاً لمتغير المرحلةالدراسية.

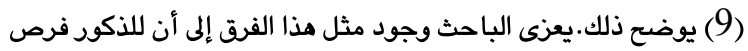

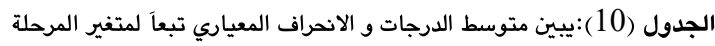

\begin{tabular}{|c|c|c|c|}
\hline الإنحراف المعياري & المتوسط الحسابي & 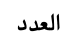 & المرحلة \\
\hline 2.683 & 35.43 & 152 & مرحلة 10 \\
\hline 2.893 & 35.24 & 108 & مرحلة 11 \\
\hline 2.665 & 34.44 & 116 & مرحلة 12 \\
\hline 2.766 & 35.07 & 376 & المجموع \\
\hline
\end{tabular}

الجدول (11): دلالة الفرق بين المتوسط الحسابي و النظري والقيم التائية المحسوية و الجدولية لدرجات الطلبة حسب الأختصاص

\begin{tabular}{|c|c|c|c|c|c|c|}
\hline \multirow{2}{*}{ 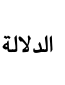 } & \multicolumn{2}{|c|}{ القيمة الفائية } & \multirow{2}{*}{ درجة الحرية } & \multirow{2}{*}{ متوسط المربعات } & \multirow{2}{*}{ مجموع المربعات } & \multirow{2}{*}{ المصادر } \\
\hline & الجدولية & المحسوبة & & & & \\
\hline \multirow{3}{*}{ دالة } & & & 2 & 34.340 & 68.680 & بين المجموعات \\
\hline & 3.04 & 4.575 & 373 & 7.505 & 2799.522 & داخل المجموعات \\
\hline & & & 375 & & 2868.202 & الكلي \\
\hline
\end{tabular}

المرحلة لايزالون في بداية حياتهم الاجتماعية والاقتصادية و لايشعرون بالكثير من مشاكل الحياة و مسؤولياتهم أقل من طلاب صفوف الآخر المنتهية، لذلك نرى بوجود مستوى عال من الموقع الضبط الداخلي

لديهم.

ج - هناك فروق ذات دلالة احصائية موقع الضبط لدى أفراد

عينة البحث وفقاً لمتغير الأختصاص ( العلمي أو أدبي ).
تم معالجة البيانات إحصائياً باستخدام نظام ال ( SPSS ) و تحليل التباين الأحادي، فأظهرت النتائج بوجود فروق ذات دلالة احصائية بين نمط و نوعية موقع الضبط لدى طلبة مرحلة الإعدادية حسب المرحلة الدراسية، و لصالح طلبة مرحلة العاشر، إذ كانت القيمة الفائية المحسوية ( 4.575 ) عند مستوى دلالة ( 0.05 ) ) و درجات الحرية (2 و 373 ) أكبر من القيمة الفائية الجدولية ( 3.04 ) ، و الجداول (10 و 11 ) يوضح ذلك. و يعزى الباحث ذلك الى كونه طلاب هذا الجدول (12): دلالة الفرق بين المتوسط الحسابي و النظري والقيم التائية المحسوبة و الجدولية لدرجات الطلبة حسب الأختصاص

\begin{tabular}{|c|c|c|c|c|c|c|c|}
\hline \multirow{2}{*}{ الدلالة } & \multirow{2}{*}{ مستوى الدلالة و درجة } & \multicolumn{2}{|c|}{ القيمة التائية } & \multirow{2}{*}{ الانحراف } & \multirow{2}{*}{ المتوسط الحسابي } & \multirow{2}{*}{ العدد } & \multirow{2}{*}{ المجموعة } \\
\hline & & الجدولية & المحسوبة & & & & \\
\hline \multirow{2}{*}{ غير دالة } & 0.05 & \multirow{2}{*}{2.326} & \multirow{2}{*}{0.559} & 2.751 & 35.14 & 203 & علمي \\
\hline & (374) & & & 2.788 & 34.98 & 173 & أدبي \\
\hline
\end{tabular}

التخصص العلمي و الأدبي، إذ كانت القيمة التائية المحسوية (0.559) عند مستوى دلالة ( 0.05 ) و درجة الحرية ( 374 ) أصغر من القيمة التائية الجدولية ( 2.326 ) ، و الجدول ( 12 ) يوضح ذلك، و يعني
تم معالجة البيانات إحصائياً باستخدام نظام ال ( SPSS ) و الإختبار

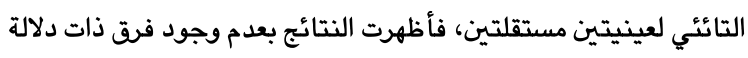
احصائية بين نمط و نوعية موقع الضبط لدى الطالبات و الطلاب حسب 
د - التعرف على دلالةالفروق بين موقع الضبط لدى أفراد عينة البحث وفقا لمتغير وضعالوالدين من الحياة:( الأب حي، الأم حية، الأم ميتة، كلاهما حيان، كلاهما ميتان). 1
ذلك أن للتخصص الطلبة ليس له تأثير في نوعية توجه و موقع الضبط لديهم. و يعزى الباحثان ذلك الى أن جميع الطلبة يأخذون نفس التربية و ينشؤن بنفس الطريق التي يحصلون أصدقائهم من تخصصات

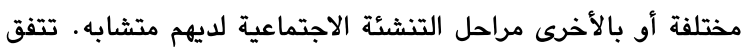
مذه النتيجة مع نتائج دراسة ( البواري، 2008 و دروزة، 2007 و و

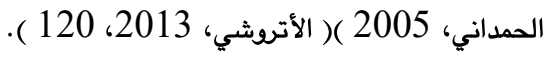

الجدول (13): دلالة الفرق بين المتوسط الحسابي و النظري والقيم التائية المحسوية و الجدولية لدرجات الطلبة حسب الوضع الحياتي للأب

\begin{tabular}{|c|c|c|c|c|c|c|c|}
\hline \multirow{2}{*}{ الدلالة } & \multirow{2}{*}{ مستوى الدلالة و درجة } & \multicolumn{2}{|c|}{ القيمة التائية } & \multirow{2}{*}{ المعياري } & \multirow{2}{*}{ المتوسط الحسابي } & \multirow{2}{*}{ العدد } & \multirow{2}{*}{ المجموعة } \\
\hline & & الجدولية & المحسوبة & & & & \\
\hline \multirow{2}{*}{ غير دالة } & 0.05 & \multirow{2}{*}{2.326} & \multirow{2}{*}{1.119} & 2.782 & 35.10 & 360 & الأب حي \\
\hline & (374) & & & 2.301 & 34.31 & 16 & الأب ميت \\
\hline
\end{tabular}

التوجه و موقع الضبط لديهم. يمكن عنف هذه النتيجة الى أن أفراد العينة و مم المراهقين أو طلبة المرحلة الإعدادية متأثرين بالعوامل الأخرى عدى وجود الأب حيث تؤثر في تنشئتهم بطريقة يتفكرون بنفس الطريقة التي يفكرون في الحياة بصورة عامة و الحياة المدرسية بصورة خاصة.

2 - فيما يتعلق بالأم:
تم معالجة البيانات إحصائياً باستخدام نظام ال ( SPSS ) و الإختبار التائئي لعينيتين مستقلتين، فأظهرت النتائج بعدم وجود فرق ذات دلالة احصائية بين نمط و نوعية موقع الضبط لدى الطالبات و الطلاب حسب التخصص العلمي و الأدبي، إذ كانت القيمة التائية المحسوية (1119) عند مستوى دلالة ( 0.05 ) و درجة الحرية ( 374 ) و إلت الصغر من القيمة

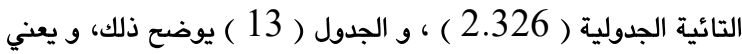
ذلك أن للعامل الوضع الحياتي لأباء الطلبة ليس له تأثير في نوعية الجدول (14) : دلالة الفرق بين المتوسط الحسابي و النظري والقيم التائية المحسوبة و الجدولية لدرجات الطلبة حسب الوضع الحياتي للأم

\begin{tabular}{|c|c|c|c|c|c|c|c|}
\hline \multirow{2}{*}{ الدلالة } & \multirow{2}{*}{ مستوى الدلالة و درجة } & \multicolumn{2}{|c|}{ القيمة التائية } & \multirow{2}{*}{ الانحراف } & \multirow{2}{*}{ المتوسط الحسابي } & \multirow{2}{*}{ 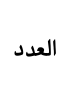 } & \multirow{2}{*}{ المجموعة } \\
\hline & & الجدولية & المحسوية & & & & \\
\hline \multirow[b]{2}{*}{ غير دالة } & 0.05 & \multirow{2}{*}{2.326} & \multirow{2}{*}{1.152} & 2.752 & 35.11 & 365 & الأم حية \\
\hline & (374) & & & 3.060 & 33.82 & 11 & الأم ميتة \\
\hline
\end{tabular}

ثم معالجة البيانات إحصائياً باستخدام نظام ال ( SPSS ) و الإختبار عينة البحث الحالي، و من جانب آخر المجتمع الكوردي ذو خاصية من التائئ لعينيتين مستقلتين، فأظهرت النتائج بعدم وجود فرق ذات دلالة حيث فراغ الأم في العائلة يملي بواسطة أفراد الآخرين من ذوي العلاقة

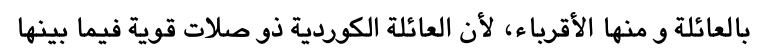
احصائية بين نمط و نوعية موقع الضبط لدى الطالبات و الطلاب حسب الخصص العلمي و الأدبي، إذ كانت القيمة التائية المحسوية ( 1.152) بين الجيرة و الأقرباء، مما يؤثر ايجاباً في عملية التنشئة الاجتماعية

عند مستوى دلالة ( 0.05 ) و درجة الحرية ( 374 ) أصغر من القيمة لأفرادها. ح - هناك فروق ذات دلالة احصائية بين موقع الضبط لدى لاده

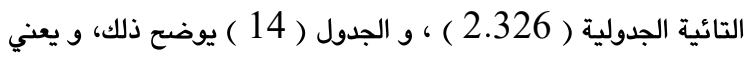
أفراد عينة البحث وفقا لمتغير الوضع الاقتصادي ذلك أن للعامل الوضع الحياتي للأم الطلبة ليس له تأثير في نوعية للعائلة:(جيد، متوسط، ضعيف).

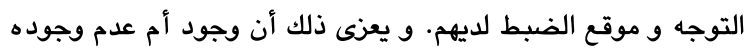
في العائلة ليس لها تأثير في عملية التنشئة و التطبيع الاجتماعي لأفراد الجدول (15): يبين متوسط الدرجات و الانحراف المعياري تبعاً لمتغير المستوى المعيشي للعائلة

\begin{tabular}{|c|c|c|c|}
\hline الإنحراف المعياري & المتوسط الحسابي & 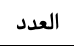 & الوضع المعيشي للعائلة \\
\hline 2.546 & 35.40 & 158 & جيد \\
\hline 2.773 & 34.83 & 209 & متوسط \\
\hline 5.255 & 34.89 & 9 & ضعيف \\
\hline 2.766 & 35.07 & 376 & المجموع \\
\hline
\end{tabular}


محمد ، نصرالدين إبراهيم / مجلة العلوم الانسانية لجامعة زاخو، مجلد:6 ، العدد:1 ، الجزء:2، ص 240- 255، آذار - 2018.

الجدول (16): دلالة الفرق بين المتوسط الحسابي و النظري والقيم التائية المحسوبة و الجدولية لدرجات الطلبة حسب الوضع المعيشي للعائلة

\begin{tabular}{|c|c|c|c|c|c|c|}
\hline \multirow{2}{*}{ 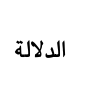 } & \multicolumn{2}{|c|}{ القيمة الفائية } & \multirow{2}{*}{ درجة الحرية } & \multirow{2}{*}{ متوسط المربعات } & \multirow{2}{*}{ مجموع المربعات } & \multirow{2}{*}{ المصادر } \\
\hline & الجدولية & المحسوبة & & & & \\
\hline \multirow{3}{*}{ غير دالة } & & & 2 & 14.817 & 29.634 & بين المجموعات \\
\hline & 3.04 & 1.947 & 373 & 7.610 & 2838.568 & داخل المجموعات \\
\hline & & & 375 & & 2868.202 & الكلي \\
\hline
\end{tabular}


م - التعرف على دلالة الفروق بين موقع الضبط لدى أفراد عينة البحث وفقاً لمتغير الوضع التعليمي للوالدين:( الأب متعلم، الأم متعلمة، كلاهما متعلمان، كلاهما غير متعلمان). الجدول (17): يبين متوسط الدرجات و الانحراف المعياري تبعاً لمتغير مير مئمان المستوى الثقافي للوالدين

\begin{tabular}{|c|c|c|c|}
\hline المعياري & الحسابي & 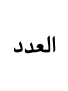 & المستوى الثقافي للوالدين \\
\hline 2.771 & 35.65 & 114 & الأب يقراء \\
\hline 3.197 & 35.29 & 17 & الأم تقراء \\
\hline 2.877 & 39.94 & 72 & كلتهما يقرءان \\
\hline \multirow[t]{2}{*}{2.627} & 34.72 & 173 & كلتهما لايقرءان \\
\hline & & 376 & المجموع \\
\hline
\end{tabular}

تم معالجة البيانات إحصائياً باستخدام نظام ال ( SPSS ) و تحليل التباين الأحادي، فأظهرت النتائج بعدم وجود فرق ذات دلالة احصائية بين نمط و نوعية موقع الضبط لدى طلبة مرحلة الإعدادية حسب متغير

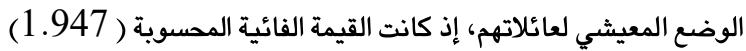
عند مستوى دلالة ( 0.05 ) و درجات الحرية (2 و 373 ) أكبر من القيمة الفائية الجدولية ( 3.04 ) ، و الجداول ( 15 و 16 ) ) يوضح ذلك. و يمكن أن نستنتج بأن الوضع المعيشي للعائلة لم يؤثر في توجه طلبة المرحلة الإعدادية نحو الحياة و أهدافهم الحياتية و الحوادث التي تحدث لهم و موقع الضبط لديهم، لذلك لديهم أراء متقارية حول هذا المواضيع، و برغم من أن النتيجة غير منطقي و لكن هذا ما تم التوصل اليه البحث الحالي.و تتفق مذه النتيجة مع دراسة ( دروزة، 2007 ) ( الأتروشي، 2013، 121 ) . الجدول (18): دلالة الفرق بين المتوسط الحسابي و النظري والقيم التائية المحسوية و الجدولية لدرجات الطلبة حسب المستوى الثقافي للوالدين

\begin{tabular}{|c|c|c|c|c|c|c|}
\hline \multirow{2}{*}{ الدلالة } & \multicolumn{2}{|c|}{ القيمة الفائية } & \multirow{2}{*}{ درجة الحرية } & \multirow{2}{*}{ متوسط المربعات } & \multirow{2}{*}{ مجموع المربعات } & \multirow{2}{*}{ المصادر } \\
\hline & الجدولية & المحسوبة & & & & \\
\hline \multirow{3}{*}{ دالة } & & & 3 & 20.603 & 61.809 & بين المجموعات \\
\hline & 2.62 & 2.731 & 372 & 7.544 & 2806.393 & داخل المجموعات \\
\hline & & & 375 & & 2868.202 & الكلي \\
\hline
\end{tabular}

2. تمتع طلبة مدارس الإعدادية بمستوى مقبول من الموقع الضبط الداخلي. 3. كان للعوامل ومتغيرات الأختصاص و الوضع الحياتي للوالدين و الوضع المعيشي للعائلة اثره في موقع الضبط لدى طلبة المرحلة الإعدادية في مركز قضاء زاخو.

4. كان لعوامل و متغيرات الجنس و مستوى الثقافي للوالدين دور في نوعية موقع الضبط لدى طلبة المرحلة الإعدادية.

$$
\text { 10. التوصيات }
$$

في ضوء نتائج البحث يوصي الباحث بما يأتي :

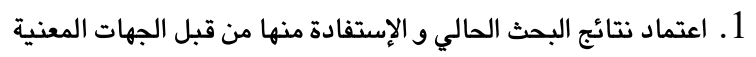
و التابعة للوزارة التربية في إقليم كوردستان العراق. 2. ضرودة معرفة الطلبة بذلك الميزة لديهم (التغذية الراجعة) مما يزداد مستوى الثقة بالنفس لديهم و يزداد بذلك الدافعية الداخلية نحو العمل و المحاولة و التحصيل و الأنجاز، و ذلك لأن يوجد أساساً العنصر

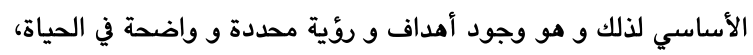
و الرضى عن الحياة، و الإيمان بمبداء النشاط و الإرادة في الحياة بصورة عامة يعتبر ضروريا لإنجاح الطالب في الحياة الدراسية والحياة العامة. 3. ضرورة إقامة ندوات علمية وتربوية من قبل أخصائيين نفسيين وتربويين من خلال أجهزة الإعلام المختلفة و السيمينارات لتوعية أولياء أمور المرامقين و المدرسين و المديرين حول معرفة ذلك الحقيقة بأن
تم معالجة البيانات إحصائياً باستخدام نظام ال ( SPSS ) و تحليل التباين الأحادي، فأظهرت النتائج بوجود فرق ذات دلالة احصائية بين نمط و نوعية موقع الضبط لدى طلبة مرحلة الإعدادية حسب متغير المستوى الثقافي للوالدين، إذ كانت القيمة الفائية المحسوية ( 2.731) عند مستوى دلالة ( 0.05 ) و درجات الحرية (3 و 372 ) أكبر من

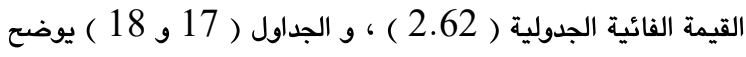
ذلك. هذا يشير إلى أن للمستوى الثقافي للوالدين تأثير في نوعية الموقع الضبط لدى الطلبة و لصالح الطلبة ذوى القدرة على الكتابة و القراءة،

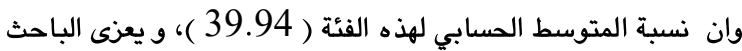
هذا إلى أن ثقافة الوالدين لها تأثيى إيجابي على الطلاب و نظرتهم إلى له أنفسهم و مساعيهم و طموحاتهم المستقبلية، لأنهم يرثدون أطفالهم و

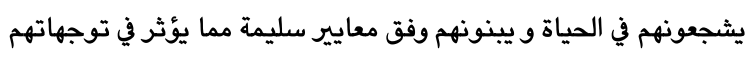
الحياتية و التحصيلية و يؤدي الى غرس الثقة العالية لديهم بأنفسهم، لذلك نرى بوجود مذا الفرق ذو دلالة إحصائية عالية. 9. الإستنتاجات كشفت نتائج البحث: 1. أن لغالبية الطلبة ضمن عينة البحث موقع الضبط الداخلي، حيث ان متوسطات النظري لهم لهذا النوع من الموقع الضبط اكبر من المتوسط النظري لموقع الضبط الخارجي، و مذا يعني يتميز موقع الضبط لدى طلبة مرحلة الإعدادية في مركز قضاء زاخو بكونه داخلياً. 
أحمد، سهير كامل ( 2003 ) . سيكولوجية الشخصية، ط. ؟ ، مركز الأسكندرية

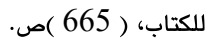

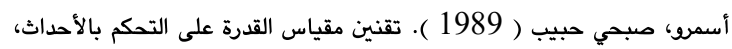

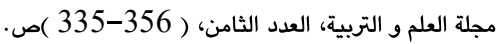

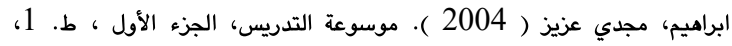

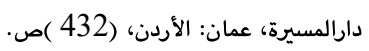

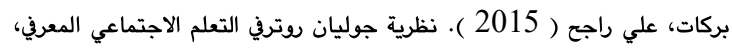

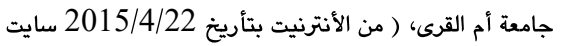
https://Www.google.iq/

بكر، جوان اسماعيل ( 2013 ). جودة الحياة و علاقتها بالانتماء و القبول / الإل

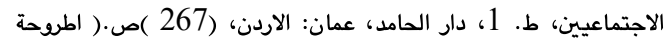
دكتوراه المنشورة ).

البكري، أمل و عجور، ناديا ( 2008 ) . علم النفس المدرسي، ط. 1، المعتز،

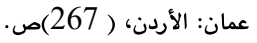

الترتوري، محمد عوض و القضاة، محمد فرحان ( 2006). المعلم الجديد دليل اليل

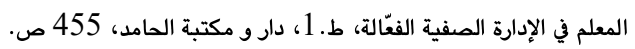

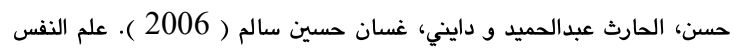

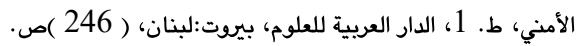

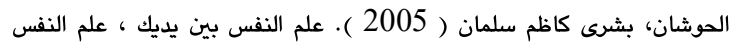

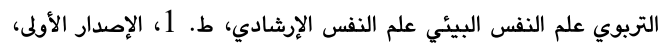
دار الشرقق، عمان: الأردن.

الرفاعي، أحمد حسين. ( 2007 ). مناهج البحث العلمي تطبيقات ادارية و الاردن

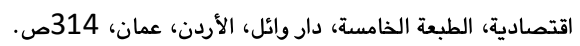

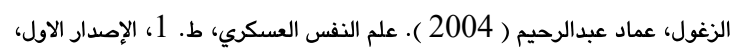

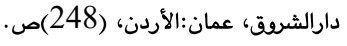

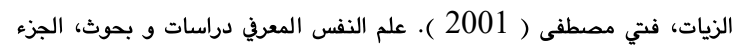

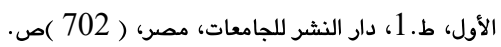

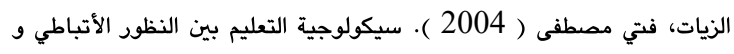
المنظور المعرفي، سلسلة علم النفس المعرفي ( 2 ( ).

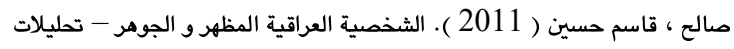
سيكوسوسيولوجية، ط. 2، ظفاف، بغداد، ( 241 ) ص.

طه، فرج عبدالقادر ( 1999 ). علم النفس و قضايا العصر، ط. 7، ط، عين للدراسات

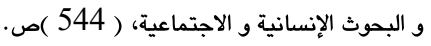

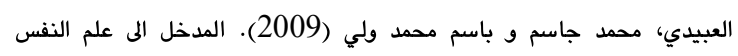

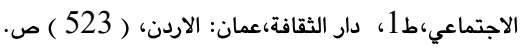

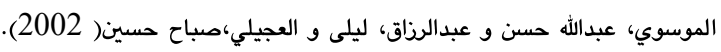

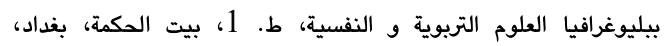
.632)

ب. م. ( 2015 ). نظرية التعلم الاجتماعي، (من الأنترنيت بتأريخ 2015/4/22 (h32)

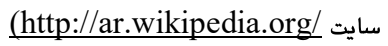

3.12. المصادر باللغة الفارسية:

اتكينسون، مارى و طرى هون بى (1383). بهداشت روانى در مدارس،ترجمة:

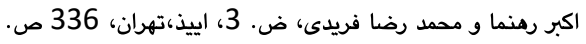

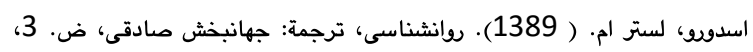

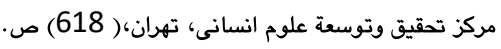

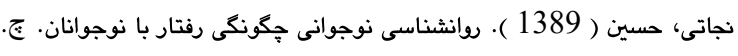

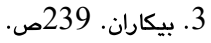

الطلبة أساساً ذو موقع ضبط الداخلي متحمسون أكثر للدراسة و بذل الجهد خلال السنة الدراسية، لذلك ينبغي استغلال تلك الطاقات و الاستعدادات و القدرات و الدافعية لديهم في سبيل توجيههم توجيهاً سليماً نحو الأهداف الدراسية و الحياتية. 4. حث المدرسين و أولياء الأمور على حجب بعض التصرفات ذات الضرد بالطلبة، المتمثل في السخرية من الطلبة و إهانة الطالب عن طريق استخدام بعض الكلمات و العبارات التي تؤدي إلى انهيار معنوياتهم أو إنخفاض مستوى الثقة بالنفس لديهم. 5. العمل على زيادة الوعي النفسي و الدراسي لدى طلبة مرحلة الإعدادية بشكل عام من خلال مشاركتهم الدورات الثقافية التي تعزن

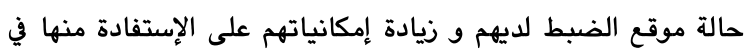
اتخاذ قرارات مناسبة الحياتية. 6. قيام الجهات المعنية في التربية بتعزيز موقع الضبط الداخلي لدى طلبة المرحلة الإعدادية لما في ذلك من مردود إيجابي على التعليم و التعلم و تمكينهم مواجهة أعباء حياتهم التربوية و التعليمية و التعلمية العليمة و الاجتماعية بسشكل عام.

\section{1. - 11 المقترحات}

استكمالا للفوائد المتوخات من البحث الحالي يقترح الباحثان إجراء ما 1. 1 1. دراسة مماثلة على تلاميذ المرحلة الأساس. 2. دراسة مماثلة على مرحلة المرامقة المتأخرة المتمثلة بالتعليم 3. دراسة حول علاقة موقع الضبط بالجوانب الأخرى للنضج كالنضج الانفعالي أو العقلي أو الأخلاقي للمرامقين.

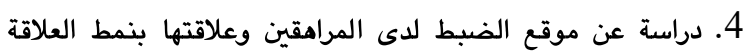
الوالدية والأبناء أو التوافق النفسي و الاجتماعي أو الصحة النفسية. 5. دراسة عن نمو التفكير الابتكاري بين المراهقين ذوي اتجاه داخلي ضمن موقع الضبط والذين ذوق اتجاه خارجي.

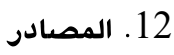

1.12. المصادر باللغة الكوردية:

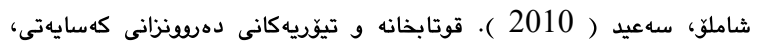

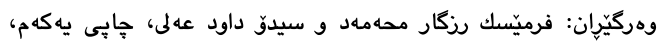

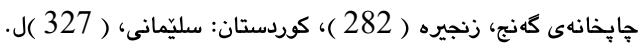

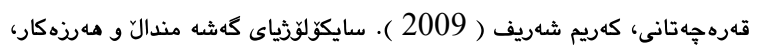

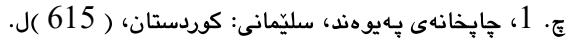

2.12. المصادر باللغة العربية: الأتروشي، عماد ابراهيم حيدر ( 2013 ). المزاج و علافته بموقع الضبط و اتخاذ

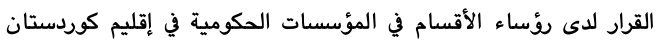

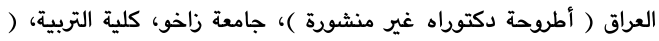
216 ) ص. (لطرو 
ب. م. ( 2015 ). ( من الأنترنيت بتأريخ 2015/4/22 / سايت http://psychology.jrank.org/pages/593/SocialLearning-Theory.html)

(2015). Social learning theory and Rotter, Jullian B. 2015 4/22 ) http://psychology.jrank.org/pages/550/Julian-BRotter.html.(

( 2015 ). The Social Learning Theory of Julian B.

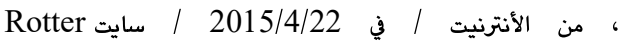
http://psych.fullerton.edu/jmearns/rotter.htm.(

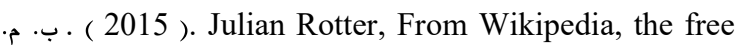

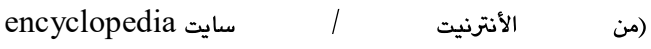
http://en.wikipedia.org/wiki/Julian_Rotter فيت نونرنيت . (2015/4/22

\subsection{2. المصادر باللغة الروسية:}

Дружинин, В. Н. ( 2000 ). Варианты жизн : очерки экзистнциальной психологии. М: ПЕРСЭ , СПб: ИМАТОН.- $135 \mathrm{c}$.

Ильин Е.П. ( 2000 ). Мотивация и мотивы. СПб.изд-во « Питер»,.-512c.

Крысько В.Г. ( 2001 ). Психологическая и педагогика : Семемы и комментарии. М. : изд во ВАЛДОПРЕСС. $368 \mathrm{c}$.

Медведев, В. И. ( $200 \overline{3}$ ). Адаптация. СПб. : ин- т мозга человека РАН, -584c.

Реан А.А. ( 1994 ). Локус контроля делинкентной личности. // Психологически журн., том.15 № 2.C.52-56.

Резник, Ю. М. и Смирнов, Е. А. ( 2002 ). Жизненных стратегии личности ( опыт комплексного анализ ). М. Институт человека РАН, Независимы ирст-т гражданского общества, 260c.

Хок, Р. ( 2008 ). 40 исследований, которые потерясли психологию/ Роджер Р. Хок. - СПб.: ПраймЕВРОЗНАК., -509 c.

Хармз, Вахид ( 2002 ). Психологическая адаптайия эмигрантов на материале исследования Иракских эмигрантов в Щвейии. СПб.. Речь, Санкт-Ретербург, - 240 с.

Шамало, Т. Н. (2008 ). Развивтия системы подготовки бакалавров оразования в России, Педагогическое образование т наука, но. 6, 7880
4.12. المصادر باللغة الانجليزية:

Burger, Jerry M. ( 1997). Personality, $4^{\text {th }}$ ed., an introductional athom pub.

Colman, M. Andrew ( 2009 ). Oxford Dictionary of Psychology, 3th ed. Oxford university press, USA, 882pp.

Coon, Dennis (1997). Essentials of psychology, exploration and application, 7 th, Brooks/Cole pub., USA.

Gibson, James 1. , Ivancevich, John m., Donnely, james H., and Konopaske , Robert (2006). Organizations, behavior's structure, processes , $12^{\text {th }}$ ed. McGraw-Hill, Irwin ,606pp.

Jones, Gareth R. , George , Jenifer M. ( 2006 ). Contemporary management, $4^{\text {th }}$ ed. McGrawHill, Irwin, ( 780 ) pp.

Jolley, Janina M. and Mitchell, Mark L. ( 1996). Lifespan development, A topical approach, Brown \& Benchmark, ( 526 )pp.

Kellogg, Robert T. and Pisacreta, Richard (2003). The best test preparation for the GRE graduate record examination psychology test, research and education association, USA, $580 \mathrm{pp}$.

Kreitner, Robert and Kinicki, Angelo (2004). Organizational behavior, $6^{\text {th }}$ ed. McGraw-Hill, Irwin ,710pp.

Meyers, Daivid G.( 2004 ). psychology, $7^{\text {th }}$ ed. , Worth pub., USA.

Myers, Daivid G. ( 2005 ). Social psychology, $8^{\text {th }}$ ed. , McGraw Hill, NY.

Passer, Micheal W. , Ronald E. Smith(2007). Psychology, frontiers and applicatios, $1^{\text {th }}$ ed., McGraw hill, USA.

Passer, Micheal W. , Ronald E. Smith(2007). Psychology, thescience of mind and behavior, $4^{\text {th }}$ ed., McGraw hill, USA.

Sarafino, Edward P. ( 2006 ). Health psychology biopsychological interaction, $5^{\text {th }}$ ed. , John Wiley \& sons , Inc, USA.

Rotter, J. and Mischel, Walter ( ب. ) . Cognitive Social Learning Theory, (2015/4/22 Site http://highered.mheducation.com/sites/00723167 99/student_view0/part3/chapter12/chapter_outli ne.html ).

Rotter J.B. (1990). Internal Versus External Control of Reinforcement: A Case History of a Variable, American Psychologist, April 1990, من الأنترنيت / / سايت/ بتأريخ 2015/4/22 (490-493 http://changingminds.org/explanations/preferenc es/locus_control.htm ) 
الملاحق

الملحق (1)

اسماء المحكمين الذين تم الاستعانة بخبراتهم في صدق المقياس

\begin{tabular}{|c|c|c|c|}
\hline الاختصاص & 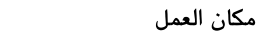 & 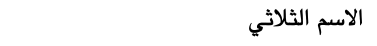 & $\Xi$ \\
\hline قياس وتقويم & جامعة دهوك /كلية التربية & أ.د. صابر عبدالله الزيباري & 1 \\
\hline علم نفس النمو & جامعة دهوك/ كلية التربية & أ.د. فاتح ابلحد فتوحي & 2 \\
\hline طرق التدريس/الرياضية & جامعة زاخو / سكول التربية & أ.م. د. أحمد قاسم محمد & 3 \\
\hline علم النفس التربوي & جامعة زاخو/ سكول التربية & م. د. خلود بشير عبدالأحد & 4 \\
\hline طرق التدريس/التاريخ & جامعة زاخو/ سكول التربية & م. د. ستار جبار حاجي & 5 \\
\hline طرق التدريس/ الجغرافيا & جامعة دموك/ عقد & م. د. عبدالمهيمن عبدالحكيم الديرشوى & 6 \\
\hline علم النفس النمو & جامعة زاخو/ سكول التربية & م· م. زاهد سامي محمد & 7 \\
\hline القياس و التقويم & جامعة زاخو/ سكول التربية & م. م. فمان أحمد محمد & 8 \\
\hline بكالوريوس -اللغة العربية & تربية زاخو/ مشرف تربوي & عبدالحميد عبدالهادي طه & 9 \\
\hline بكالوريوس -علم النفس & تربية زاخو/ مشرف تربوي & اسماعيل عبدالله أحمد & 10 \\
\hline بكالوريوس اللغة العربية & تربية زاخو/ مشرف تربوي & سليمان علي شهاب & 11 \\
\hline بكالوريوس -لغة الكوردية & تربية زاخو/ مشرف تربوي & علي صديق ابراهيم & 12 \\
\hline بكالوريوس -إدارة & تربية زاخو/ مشرف تربوي & محي الدين نورالدين حسن & 13 \\
\hline
\end{tabular}

(2) الملحق)

مقياس موقع الضبط لدى الطلبة باللغة الكوردية ( البادينانية ) زانينعهها زاخوّ موقي

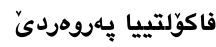

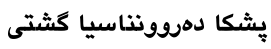
قوتابى/ قوتابيا هيرّا سلاثة و ريّزّ....

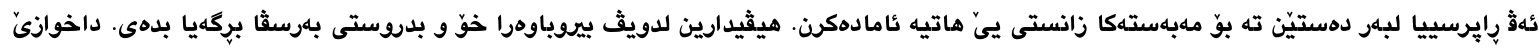

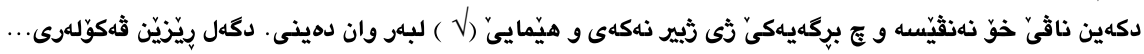
زانيارى: - -

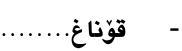

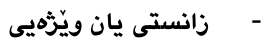

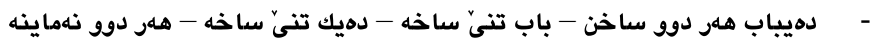

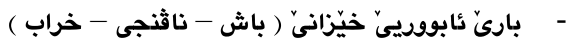

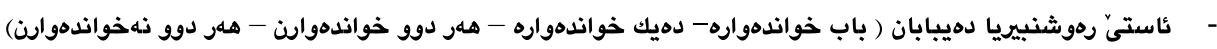

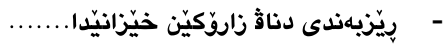




\begin{tabular}{|c|c|c|c|}
\hline 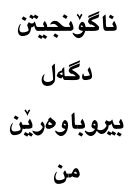 & ديروَّنجيتن & برگكه & j \\
\hline & & ب باوهرا من رِابوونا من ب ئه نجامدانا ئهرك و كاريّن خوّ ل مال بنهماييّ بدهستثهئينانا نمريّن بلنده د خواندنيّدا. & .1 \\
\hline & & 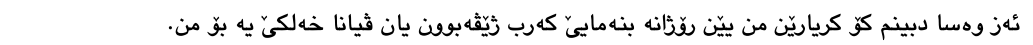 & .2 \\
\hline & & ب ديتنا من كرنكى دانا دهيبابيّن من بو هاريكاريكرنا من د ثيانا رِدذانهدا بناسيّ سهرهكييّ سهركهفتنا منه. & .3 \\
\hline & & ب باوهرا من، من شيانيّن باش ييّن هدين وان كاودانيّن كارتيّكرنى د ثيانا من دا دكهن بكوهورِم. & .4 \\
\hline & & 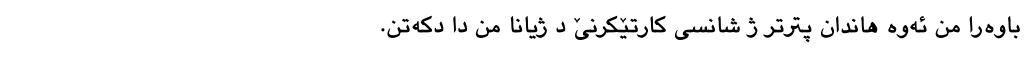 & .5 \\
\hline & & 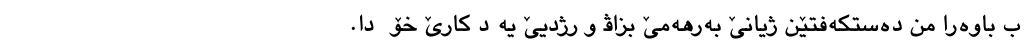 & .6 \\
\hline & & باوهرا من ئهوه كه ساتيهكا بهيّز رِّلنّ هلى د يهيداكرنا خهثاليّن باش. & .7 \\
\hline & & ئهز د ويَّ باوهريّدامه دهيناندنا بِيلانيّن رِّدانه دهليفيّ سهركهفتنى بِترتر دكهتن. & .8 \\
\hline & & هـ هست دكهم من شيانيّن باش يِين ههين دا برياريّن هارهنفيس سازيّن رُيانا خوّ بدهم. & .9 \\
\hline & & ئهز كهله جاران لومهه هييا خوّ دكهم ربهر كوّ من ج شانسهك د ريانيّ دا نينه. & .10 \\
\hline & & ئهز دبينم ريانا من يا رِدَانه هـمى دووباره و رِّتينه جونكى ئهز بيّ شانسم. & .11 \\
\hline & & 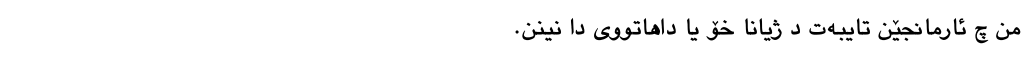 & .12 \\
\hline & & 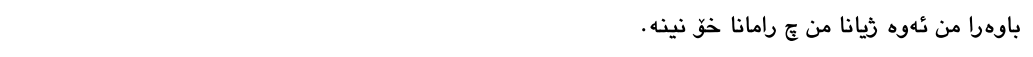 & .13 \\
\hline & & 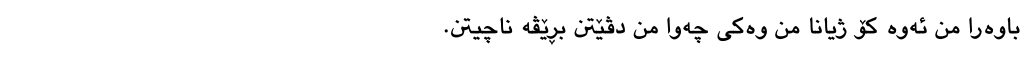 & .14 \\
\hline & & خوّزيكيّن هنديّ دخوازم دهليثهيهك ديتر بو من ههلكهفتبايه دا من رُيانهك نوى و باشتر بوّ خوّ مهلبرًارتبايه. & .15 \\
\hline & & 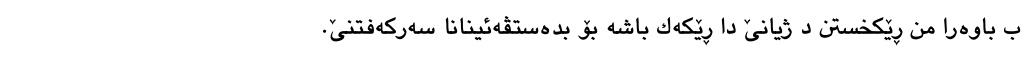 & .16 \\
\hline & & 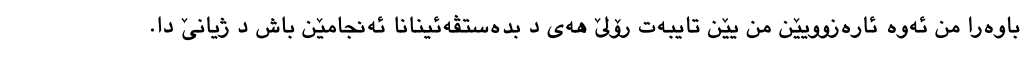 & .17 \\
\hline & & 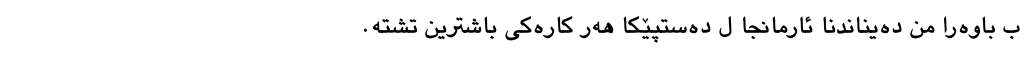 & .18 \\
\hline & & باوهرا من ئهوه هـر كهسهى ويستهكا بهيّز نهبيتن د ريانا خوّ دا سهرناكهثيتن. & .19 \\
\hline & & ب باوهرا من ساخلهمييا تاكى رِّلَ ههى د كههشتن ب تارمانجيّن خو. & .20 \\
\hline & & ئهز دبينم هـر كهسكيّ شيانيّن مادى ييّن باش نهبن د ثيانيّ دا سهرناكهثيتن. & .21 \\
\hline & & 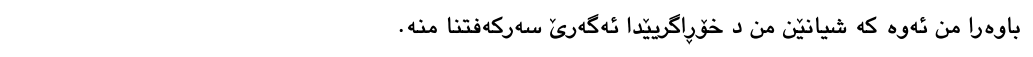 & .22 \\
\hline & & باوهرا من نهوه ههستكرن ب بهريرسيارهتيكّ هاريكارييا من دكهتن نارمانجيّن باش د زيانيّ بدهست خوّثه بينم. & .23 \\
\hline & & 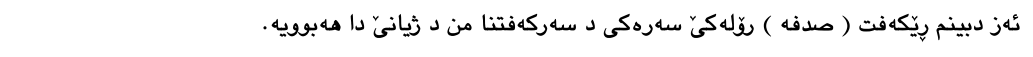 & .24 \\
\hline & & 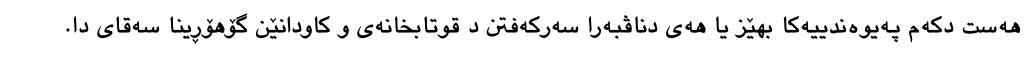 & .25 \\
\hline & & 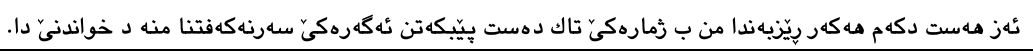 & .26 \\
\hline
\end{tabular}




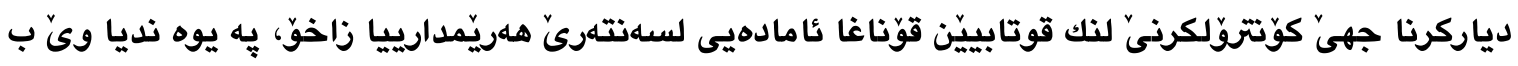

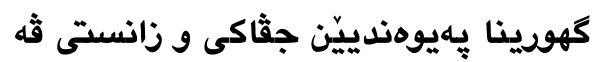

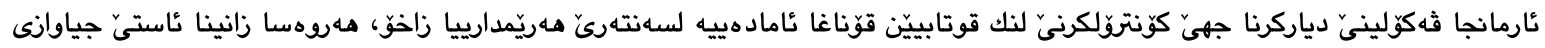

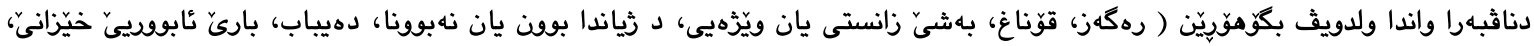

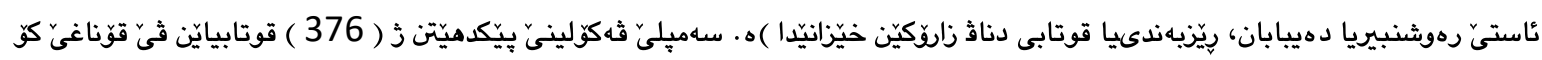

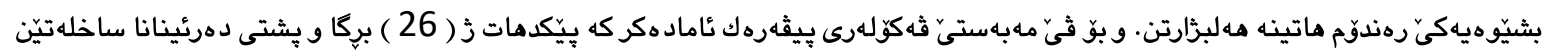

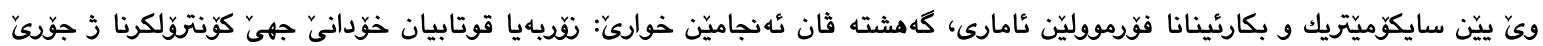

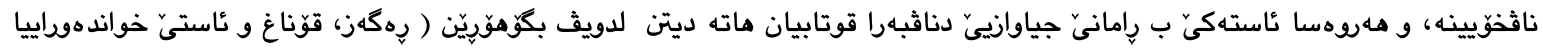

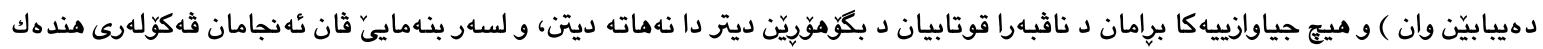

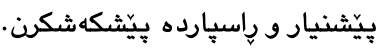

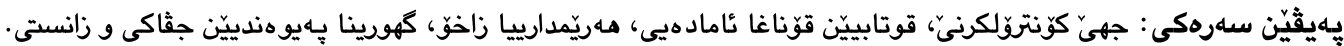

\section{Studying the Location of the Control of the Students of the High Schools in Zakho District and its Relation to the Social and Scientific Variables}

\begin{abstract}
:
The search aims to identify locus of control among high school's students in the center of Zakho, to identify differences between them depending on the variables (Gender, specialty, class, state of parents' life, parent's level of cultural, and family's economic level and rank of student's birth). The sample of research consisted of (376) students selected randomly from Zakho high schools. For this purpose, researcher prepared a scale, consisting of (26) items, where extracted psychometric properties, and for the purpose of processing data was used appropriated statistical methods. And the results show that most of the students have internal locus of control, also found there is statically significant differences according to variables of (sex, class, and level of parent's academic situation) and also found there is no statically significant differences according to variables of (specialty, state of parents' life, and family's economic level), and in the light of the results researchers presented some recommendations and proposals.
\end{abstract}

keywords: Location of the control, High Schools, Zakho District, Social and Scientific Variables. 